INDUSTRIAL MARKETING MANAGEMENT

Peter J. LaPlaca, Ph.D., Editor-in-Chief

24 Quarry Drive, Suite 201

Vernon, CT 06066-4917

Phone (860) 875-8017

Plaplaca@JournalIMM.com

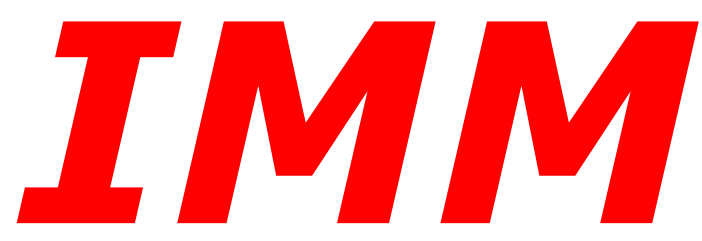

The International Journal of Marketing for Industrial and High-Tech Firms

June 102014

Nektarios Tzempelikos

Anglia Ruskin University

Lord Ashcroft International Business School

East Road

Cambridge CB1 1PT

Dear Dr. Tzempelikos,

We have completed the review process of the following manuscript:

Linking Key Account Management Practices to Performance Outcomes

submitted by you and Spiros Gounaris, and I am pleased to inform you that the revised paper has been accepted for publication in Industrial Marketing Management for the special issue From Strategy Frameworks to Value-in-use: Implementing Strategies and Theories of B2B Marketing and Sales Management.

Please follow the instructions on the form entitled "Submission Requirements for Accepted Papers" that is also attached to the e-mail. If all instructions are not followed EXACTLY, the paper will NOT be published. Please note the new option for including color graphics on the Web-based (PDF) version of your manuscript. I think that the color graphics in the WEB and PDF versions of the articles really adds to their impact and readability.

Please note that we will not change the affiliation for any author once the proofs have been corrected. If an author changes affiliations after the time the corrected proofs have been received and before the article appears in a bound issue of IMM, we will add a footnote on the first page of the article indicating the change. No changes or footnotes will be made after the article appears in a bound issue of the journal.

Open-Access Option - I would also like to inform you of another new option that can make your article more widely available (and possibly lead to more citations for it.) Authors of articles in IMM now have the option to pay a fee to make their article freely available to non-subscribers. In other words, authors are given the choice of making their own article Open Access; the charge for article sponsorship is $\$ 3,000$. This charge is necessary to offset publishing costs - from managing article submission and peer review, to typesetting, tagging and indexing of articles, hosting articles on dedicated servers, supporting sales and marketing costs to ensure global dissemination via ScienceDirect, and permanently preserving the published journal article. The fee excludes taxes and other potential author fees such as color charges which are additional. Many universities have a special fund to pay for these fees; check with your university if you want this option and please indicate so on the submittal form. Elsevier will bill you directly for this.

Video Highlights Option - IMM also now has the option of adding video clips to your article on the web. These can be imbedded slide shows with audio or brief (2-4 minutes) videos of the authors speaking 
directly to the readers. They can be inserted several places in your posted article. Research has shown that these video highlights increase citations of articles. Complete instructions are shown in the attachment to the e-mail containing this letter.

There are two publication dates. The first is when it appears on the IMM web site as an "Article in Press." It is then available for reading and downloads by subscribers to IMM. This happens 3-4 weeks after the final paperwork is received by the publisher. The second publication date (which will replace the first one on your $\mathrm{CV}$ ) is when the article appears in a hard copy issue of the journal.

To facilitate the process, please e-mail the final manuscript and manuscript submittal form to specialeditor@hisplace. I will send you an e-mail confirmation as soon as the material arrives.

I look forward to seeing your article in print.

Sincerely,

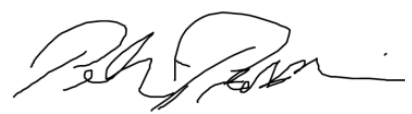

Petri Parvinen

Special Guest Editor 


\title{
Linking Key Account Management Practices to Performance Outcomes
}

\author{
By \\ Nektarios Tzempelikos, $\mathrm{PhD}^{*}$ \\ Senior Lecturer in Marketing \\ Anglia Ruskin University \\ Lord Ashcroft International Business School \\ East Road \\ Cambridge CB1 1PT \\ Room: Lab 322 \\ Tel: +44 8451962664 \\ Email: nektarios.tzempelikos@anglia.ac.uk \\ Spiros Gounaris, $\mathrm{PhD}$ \\ Professor of Marketing \\ University of Strathclyde Business School \\ Department of Marketing \\ Sir William Dunkan Building \\ 130 Rottenrow \\ Glasgow G4 0GE \\ Room 5.10 \\ Tel: +44 1415483233 \\ Email: spiros.gounaris@strath.ac.uk
}

* Lead author for correspondence 


\section{Biography}

Nektarios Tzempelikos is Senior Lecturer in Marketing in the Lord Ashcroft International Business School, Anglia Ruskin University. His research interests include key account management, relationship marketing and customer value in the business-to-business context. His research has been published in the Journal of Business \& Industrial Marketing, the Journal of Business-to-Business Marketing, the Journal of Strategic Marketing, the IMP Journal and the Journal of Relationship Marketing among others.

Spiros Gounaris is Professor of Marketing at the Department of Marketing of the University of Strathclyde Business School. He is also director of $\mathrm{PhD}$ studies at the University of Strathclyde Business School. His research interests include services marketing, internal marketing, marketing theory and strategy, key account management and business-to-business marketing. His work has been published in many prestigious American and European journals including the Journal of Product Innovation Management, the Journal of Business Research, Industrial Marketing Management, the European Journal of Marketing, the Journal of Services and the Journal of Service Management, and he has received various distinctions and awards. He is the author of two books and sits on the editorial board of the Journal of Service Research and Industrial Marketing Management. 


\section{Research highlights}

- KAM practices at strategic, organizational, tactical and control levels emerge as key determinants of performance outcomes.

- KAM practices positively affect financial performance/dyadic outcomes via relational capabilities and -outcomes mediation.

- This mediating role indicates that the relationship between the two parties is a critical aspect of KAM implementation

- In light of the above, the practice of KAM should not be viewed only within the supplier-firm boundaries. 


\title{
Linking Key Account Management Practices to Performance Outcomes
}

\begin{abstract}
Many suppliers practise relational strategies that aim to achieve competitive advantage through a collaborative business relationship with their customers. Key account management (KAM) is one such relational strategy suppliers rely upon to manage their relationships with strategically important customers. Yet suppliers still struggle to put such programs into practice effectively, most likely because academic investigation has yet to report on what actions explain the performance of KAM initiatives. Aiming to fill this gap, we first identify a set of key KAM practices at the strategic, organizational, tactical and control levels of management. Next, we examine how these practices explain the performance of KAM through the mediating effect of the supplier's relational capabilities and the relational outputs such capabilities produce. The results provide support for most of the hypothesized relationships, showing that the identified practices positively affect performance and dyadic outcomes through the mediation coming from the variables examined. From a theoretical perspective, the study adds to our understanding of the factors underlying effective KAM practices. From a managerial perspective, the results provide insights into how suppliers can achieve KAM effectiveness through relationship-oriented activities, skills and outcomes.
\end{abstract}

Keywords: Key account management, Practices, Relationship marketing, Empirical research 


\section{Introduction}

Literature widely recognizes the importance of a relationship marketing approach in managing customer relationships (Morgan \& Hunt, 1994), particularly in the business-to-business (B2B) markets where customers are fewer and more powerful, markets are rather stable and buyer-seller relationships are complex and interdependent (Heide \& John, 1992). This shift from transactional to relationship marketing sparked a new philosophy in managing the relationship with certain strategically important accounts (Millman \& Wilson, 1995): "Key Account Management” (KAM) (Abratt \& Kelly, 2002). A key account (KA) is a customer identified by the supplier as being of strategic importance (Millman \& Wilson, 1995). In essence, KAM involves customization of products and services to meet the needs of the KA, while customers not classified as KA receive little, if any, customization (Salojärvi, Sainio \& Tarkiainen, 2010). As such, KAM is the implementation of relationship marketing in business markets (cf. Ivens \& Pardo, 2007; Guenzi, Pardo \& Georges, 2007) allowing a shift from short-term, transactional orientation to more long-term, strategic, mutually beneficial and collaborative relationships (Ryals \& Humphries, 2007).

To achieve this shift, though, certain significant changes are necessary that will affect not only procedures but also the practical and organizational configuration of the supplier (Homburg, Workman \& Jensen, 2000). While previous studies report on the significant effect that the transition to more customer-centric organization has on company performance (Homburg, Workman \& Jensen, 2002; Workman, Homburg \& Jensen, 2003), the implementation process remains surprisingly overlooked (Wengler, Ehret \& Saab, 2006; Davies \& Ryals, 2009).

Hence, to fill this gap, this study seeks to discuss and empirically examine a model of performance outcomes in relation to specific aspects of KAM practices. Drawing on a systematic review of the extant literature, we identify four pertinent dimensions of KAM practices (Strategic, Organizational, Tactical and Evaluative) that capture key aspects of every KAM initiative. We then examine their impact on the performance of the KAM program through the mediating effect of 
specific relational capabilities and outcomes. In doing so we examine both the financial and the dyadic facets of KAM performance.

This study seeks to contribute to the extant literature by identifying an empirically derived set of specific salient KAM practices that explain the supplier's performance in practicing KAM. A second contribution comes from the investigation of the mediating role that relational capabilities and outcomes have in explaining the relationship between KAM practices and KAM performance. As a result, it is possible to produce a comprehensive framework to describe in a holistic manner the antecedents of two significant aspects (financial and dyadic) of KAM performance. This is the third contribution this manuscript seeks to make. In addition, these theoretical contributions are also relevant for practitioners as demonstrating how specific dimensions of KAM implementation relate to the success of KAM can inform the implementation of the KAM initiatives.

The rest of the manuscript is organized as follows: First, we review the extant literature to develop pertinent hypotheses to lead the examination of the research model underlying this investigation. Next, the methodology and the results from the data analysis follow. The discussion and implications and then the limitations and directions for future research conclude this manuscript

\section{Literature Review, Research Model and Hypotheses}

\subsection{Carrying Through the KAM Initiatives Across Different Levels of Implementation}

The configuration of a KAM program depends on internal practices (Storbacka, 2012), which, like any other managerial practice, extend at four levels: strategy formation, organizational structuring, tactical implementation, and evaluation and control (Davies \& Ryals, 2009).

On the strategy formation level, a crucial parameter of the KAM program is account planning and selection, which can be considered equivalent to the "segmentation and targeting" process but applied at the individual account level. While the concept of KAM has emerged from that of "National Account Management" (cf. Shapiro \& Moriarty, 1984), using the actual or potential size of orders an account can generate is no longer considered to be an appropriate way to identify a KA. 
Planning ahead for the future and deciding on the use of the limited resources available to the supplier requires identification of the KA on the grounds of their ability to facilitate the supplier's effort to attain specific strategic goals and objectives, which underlie the process of KA identification and targeting (Woodburn \& McDonald, 2011). Based on a specific set of account selection criteria that reflect the supplier's strategic objectives (cf. Ryals \& McDonald, 2008), the supplier will need to assess the (strategic) attractiveness of different accounts and ensure a balance between the resources available to the firm and the number of KAs the supplier can sustainably maintain in the long run.

In addition to appropriate account planning, the implementation of a KAM initiative at the strategic level requires increased involvement of the top management since their intervention in decision making is critical for the performance of the firm (Workman et al., 2003). Through this intervention, the top management helps to improve the company's alignment with the environment in general (Carpenter, Geletkanycz \& Sanders, 2004). When it comes to the company's relationship with the KA, top management will get involved to provide direction, ensure commitment across the organization and align the organization's innovativeness with the needs of the KA (Millman \& Wilson, 1999). The KAM program also benefits from the involvement of the top management at the strategic level because through their intervention resources needed to meet the needs of the KA become available and are allocated among different KAs according to the strategic relevance of the account (Gounaris \& Tzempelikos, 2013). Not surprisingly, recent empirical research demonstrates the benefit of having the top management involved with the KAM program at the strategic level (Guesalaga, forthcoming 2014) as, in addition to all the above, KA managers very often lack authority over the other departments of the firm (Homburg et al., 2002). Hence the more the top management gets involved at this higher, strategic level the easier it becomes to achieve cross-functional coordination (Salojärvi \& Saarenketo, 2013).

Moreover, because coordination across the different departments is such an important issue, the implementation of the KAM program also requires action at the organizational level. Such action ensures that the configuration of the supplier's organization facilitates the response to the needs of the KA and the implementation of the various initiatives the program includes (Davies \& Ryals, 2009). 
To this end, the first step is ensuring the necessary cross-functional awareness and understanding of the significance KAs have for the supplier in attaining specific strategic goals, while generating the required interdepartmental cooperation and commitment in serving their needs (Workman et al., 2003; Zupancic, 2008). Establishing a "KAM esprit de corps", defined as the effort to get people (from different departments) involved in (responding to) the management of the KA and feeling obligated to the common goals and to each other (Workman et al. 2003, p. 10), is a necessary quality of the supplier's organizational configuration. A strong sense of KAM esprit de corps thus reflects the actions taken at the organizational level to ensure managers and employees are willing to cooperate in serving the KA beyond the boundaries of departmental responsibility or departmental tribalism (Salojärvi \& Saarenketo, 2013; Guesalaga \& Johnston, 2010).

However, in addition to the esprit de corps, organizing the monitoring of the KAM program and the supplier's reaction around interdepartmental teams is an additional organizational prerequisite for aligning the supplier's offering with the needs of the KA. A single KA manager is unlikely to hold the necessary expertise and capacity to manage the KA alone (Salojärvi et al., 2010). In contrast, a team allows the supplier to draw upon a set of diverse skills (Salojärvi \& Saarenketo, 2013) while at the same time enabling the coordination of a complex value-generation process that cuts across the supplier's different product categories and functional units (Moon \& Armstrong, 1994). Consequently, a consistent customer experience can be delivered (Harvey, Novisevic, Hench \& Myers, 2003).

The next level to consider is the tactical one. KAM initiatives are designed not only to manage strategic accounts but, more importantly, to increase the value the KA derives from the relationship with the supplier (Pardo, Henneberg, Mouzas \& Naudè, 2006). KAM requires strong relational capabilities and allocation of resources to the most strategically important customers (Storbacka, 2012). As such, KAM is a way to implement the principles of relationship marketing, of which the most important is customization (Aijo, 1996) in the B2B context (Guenzi et al., 2007; Ivens \& Pardo, 2007). Consequently, the key facet of KAM implementation at the tactical level is the supplier's willingness and ability to produce an offering for the KA that is tailored to the individual needs of this specific account (Wengler et al., 2006). 
Finally, the evaluation and control level captures the formal monitoring of the KAM initiatives and assesses whether the relationship with the KA serves both the financial and the strategic objectives of the supplier. While formality in general has been acknowledged to reduce flexibility and time of reaction (Jaworski \& Kohli, 1993), when it comes to monitoring and control, formal tracking systems allow the management a regular and consistent picture of company performance (Kirca, Jayachandran \& Bearden, 2005). Hence, a formal performance monitoring system improves the company's reaction time when performance deviates from objectives. This is particularly important for both the financial and the relational performance objectives of the KAM program at the account level since, while the latter are clearly important from the relationship marketing perspective, the former are equally crucial if KAs are to be held financially responsible, as they ought to be (Woodburn \& McDonald, 2011).

\subsection{Relational Capabilities}

While the practices discussed in the previous section of the manuscript may well have an impact on the outcome of the KAM program, a resource-based view of the firm (Wernerfelt 1984) provides the theoretical background to understand more precisely how such practices generate value for the KA and, consequently, translate into specific performance benefits for the supplier (Barney, Wright $\&$ Ketchen, 2001). Although any company or manager can try to adopt such KAM practices, unless certain capabilities are present the effect on performance will be less than expected.

Given the relational nature of the KAM initiatives, the supplier needs to develop certain relational capabilities (Srivastava, Shervani \& Fahey, 1998) before any initiative can be successful (Cannon \& Perreault, 1999). To capture this perspective, we focus on information sharing and conflict resolution, which span the boundaries of the firm and hence are critical for the success of the KAM program (Ryals \& Humphries, 2007; Richards \& Jones, 2009; Millman \& Wilson, 1999).

More specifically, information sharing captures the extent to which the two organizations exchange relevant and often "confidential" information that helps both parties to understand each other's position within the relationship (Cannon \& Homburg 2001). The open and frequent flow of information, especially of a proprietary nature, reflects the willingness of both parties to share such 
information (Cannon \& Perreault, 1999), indicating thus their joint commitment to the relationship and the trust each part has for the other, while allowing a comprehensive, accurate and timely understanding of each other's needs (Moorman, Zaltman \& Deshpandé, 1992).

Conflict resolution, on the other hand, is defined as the degree to which disagreements are resolved productively, clearing the air of tension and ill will (Anderson \& Narus, 1990). Conflicts often occur in buyer/seller relationships due to the inherent interdependencies between the parties (Mohr \& Spekman, 1994). Suppliers implementing KAM effectively have developed well the mechanisms that enable them to resolve conflicts that occur in relationships in a highly flexible manner (Millman \& Wilson, 1999; Richards \& Jones, 2009).

\subsection{KAM Performance}

As noted already, in addition to financial objectives KAM aims to build mutually beneficial long-term relationships with the KA. Consequently, the benefits of KAM are not just financial (Ivens $\&$ Pardo, 2007). Further to the financial aspect of effectiveness, previous research has identified a relational/dyadic dimension of effectiveness for successful KAM programs (Richards \& Jones, 2009; Guenzi, Georges \& Pardo, 2009; Ivens \& Pardo, 2007), especially since serving certain KAs can be unprofitable for the supplier, who then recovers the loss indirectly (Ryals \& Holt, 2007). Thus, we approach the effectiveness of KAM on the basis of both relational (dyadic) and financial outcomes, relying on the work of Palmatier, Dant, Grewal and Evans (2006) to capture the relational (dyadic) dimension of effectiveness as reflected in the degree of cooperation between the supplier and the KA.

Nevertheless, the relationship between the implementation of the KAM program and the outcomes of the program is not direct. Rather, a number of relational outcomes, which in the extant literature have been suggested to capture different facets of what has been termed "relationship quality" (Crosby, Evans \& Cowles, 1990), mediate this relationship (Palmatier et al., 2006). While the literature is inconclusive, researchers tend to agree that satisfaction, trust and commitment are key relational outcomes mediating the effect of KAM practices on KAM performance (Richards \& Jones, 2009; Alejandro, Souza, Boles, Helena, Ribeiro \& Monteiro, 2011; Ivens \& Pardo, 2007; Homburg et al., 2002). More specifically, satisfaction defines the (positive) affective state resulting from the 
appraisal of all aspects of an exchange relationship (Geyskens, Steenkamp \& Kumar, 1999). Trust is described as the perceived credibility and benevolence of the supplier (Doney \& Cannon, 1997). Commitment is the desire to continue the relationship in the future and the willingness to work to maintain it (Anderson \& Weitz, 1992). Hence, to meet the objectives of this investigation we focus on these three relational outcomes.

\subsection{Research Framework and Hypotheses}

Following on from the precedent review of the pertinent literature, Figure 1 depicts the research framework underlying this study with KAM practices as antecedents of the KAM outcomes. In addition, the potential mediating role of relational capabilities is examined. In the next paragraphs we develop research hypotheses to guide our study.

\section{PLACE FIGURE 1 ABOUT HERE}

\section{The effect of $K A M$ practices at the strategic level on relational outcomes}

Account planning and selection relates to corporate strategy as it ensures commitment from company management to assign the required resources to develop the account in such a way that the identified potentials can be realized (Storbacka, 2012). Account planning and selection can encompass a range of activities from the collection and systematic analysis of market information (Millman \& Wilson, 1995) and an analysis of the relationship (customer's value-creating process, value capture, future business potential) (Storbacka, 2012) to an action plan (Ryals \& McDonald, 2008). Traditionally, KA managers had little interest in formal account planning (Davies \& Ryals, 2013). However, the increasing recognition of the role of account planning in the inter-organizational alignment (Storbacka, 2012) and a deeper knowledge of customer operations (Davies \& Ryals, 2013) indicate that account planning can contribute to the achievement of collaborative relationships. Thus:

$\mathrm{H} 1_{\mathrm{a}}$ : Account planning and selection is positively related to satisfaction

$\mathrm{H} 1_{\mathrm{b}}$ : Account planning and selection is positively related to trust

$\mathrm{H} 1_{\mathrm{c}}$ : Account planning and selection is positively related to commitment 
Top management involvement also contributes to the achievement of relationship outcomes (Workman et al., 2003). Specifically, initiatives of top management such as meeting with the customer's people are highly appreciated by KAs as they get the feeling that they are important to the supplier (Gounaris \& Tzempelikos, 2013). This shows commitment in the eyes of the customers (Millman \& Wilson, 1999), which may lead to greater involvement of the customer's top management and a deepening of the overall relationship (Workman et al., 2003). In a similar vein, Salojärvi et al. (2010) found that top management involvement is positively related to customer knowledge utilization, which contributes to effective responses to the needs of KA. Furthermore, top management is found to affect KAM effectiveness through the improved performance of KA managers. In particular, Homburg and Stock (2004) show that customer contact by top management is perceived by KA managers as a support to their job and a source of motivation, which can boost their effort and eventually improve customer satisfaction. However, it is likely that top management involvement in KAM can also be detrimental, mainly because KA managers may perceive top management involvement as an attempt to undermine their role as the primary contact (Guesalaga \& Johnston, 2010). This requires top managers to actively participate in KAM relationships but in a way that does not conflict or overlap with the role of KA managers. This will lead to better intra-firm coordination and eventually to more effective responses to KA. Thus, we hypothesize that:

$\mathrm{H} 2_{\mathrm{a}}$ : Top management involvement is positively related to satisfaction

$\mathrm{H} 22_{\mathrm{b}}$ : Top management involvement is positively related to trust

$\mathrm{H} 2_{\mathrm{c}}$ : Top management involvement is positively related to commitment

\section{The effect of KAM practices at the organizational level on relational outcomes}

Developing strong bonds with customers requires the participation of people throughout the organization (Homburg et al., 2000). Establishing esprit de corps is important in this respect. In particular, esprit de corps fosters the exchange of market and customer information across the firm (Fisher, Maltz \& Jaworski, 1997). Moreover, esprit de corps is likely to increase cohesion and a feeling of togetherness among people in the firm (Geiger \& Turley, 2005). As such, establishing esprit de corps supports the building of a cross-functional expertise related to sales, production and 
technical needs of the KA (Salojärvi \& Saarenketo, 2013) and thereby contributes to the achievement of relational outcomes from the relationship (Workman et al., 2003). Thus, we hypothesize that:

$\mathrm{H}_{\mathrm{a}}$ : $\quad$ KAM esprit de corps is positively related to satisfaction

$\mathrm{H}_{\mathrm{b}}$ : $\quad$ KAM esprit de corps is positively related to trust

$\mathrm{H} 3_{\mathrm{c}}$ : $\quad$ KAM esprit de corps is positively related to commitment

Consistently, previous research suggests that the use of teams can improve buyer-seller relationships. First, the establishment of teams facilitates the development of customer-specific knowledge (Salojärvi et al., 2010) and its flow throughout the organization (Nätti, Halinen \& Hanttu, 2006). This new customer knowledge can be utilized in the development of new products, services and processes and can further result in improving customer relationships (Harvey et al., 2003). Second, establishing KAM teams signals to the customers that the supplier classifies them as customers of special status (Ivens \& Pardo, 2008). As customers feel important they are likely to enhance the relationship into a more collaborative and strategic partnership (Salojärvi \& Saarenketo, 2013). Consistently, Arnett, Macy and Wilcox (2005) found that the use of teams increases collaboration and relationship commitment in KAM relationships. On these grounds, we hypothesize that:

$\mathrm{H} 4_{\mathrm{a}}$ : Use of teams is positively related to satisfaction

$\mathrm{H} 4_{b}$ : Use of teams is positively related to trust

$\mathrm{H} 4_{\mathrm{c}}$ : Use of teams is positively related to commitment

\section{The effect of KAM activities (tactical level) on relational outcomes}

KAM activities also provide a number of benefits to the KA. First, customers can only identify and evaluate a supplier's commitment to the relationship based on what they see and observe, that is, concrete actions. Hence, KAM activities signal supplier commitment, which can deepen the trust with the account (Workman et al., 2003). Second, KAM activities (e.g. product/service adaptations or taking over a customer's workload) contribute to customer competitiveness by providing unique products and features that allow the customer to differentiate from competition either on the basis of quality or of cost (Day, 2000). Overall, providing a "red carpet" treatment through specific KAM 
activities provides benefits to the KA that can lead to a desire to strengthen the relationship. Thus, we hypothesize that:

$\mathrm{H} 5_{\mathrm{a}}: \quad$ KAM activities are positively related to satisfaction

$\mathrm{H} 5_{\mathrm{b}}$ : $\quad$ KAM activities are positively related to trust

$\mathrm{H} 5_{\mathrm{c}}$ : KAM activities are positively related to commitment

\section{The effect of KAM program evaluation on relational outcomes}

A final step in the implementation process is the evaluation of the KAM program. KAM relationships can have a number of relational outcomes such as trust and commitment which, in turn, lead to improved performance in the market such as revenue growth and market share (Workman et al., 2003). This requires a frequent and systematic process of evaluating the potential outcomes, both financial and relational, of a KAM program to identify any areas where further improvement is needed (Ojasalo, 2001) and, consequently, enhance the overall value to the customer (Storbacka, 2012). In addition, KAM evaluation will allow a better and more balanced allocation of resources in the customer portfolio, which will enable the supplier firm to concentrate and further invest resources in collaborative relationships with accounts of higher value to the firm (Storbacka \& Nenonen, 2009). On these grounds, we propose the following hypotheses:

$\mathrm{H}_{\mathrm{a}}$ : KAM evaluation is positively related to satisfaction

$\mathrm{H}_{\mathrm{b}}$ : KAM evaluation is positively related to trust

$\mathrm{H6}_{\mathrm{c}}$ : KAM evaluation is positively related to commitment

\section{Relational outcomes and financial performance}

Previous research provides evidence for the link between KA performance and the relational outcomes that are developed in the relationship between suppliers and KA (Jones, Richards, Halstead \& Fu, 2009; Richards \& Jones, 2009; Alejandro et al., 2011; Workman et al., 2003). Specifically, if satisfaction with, trust in and commitment to a supplier increase, the supplier's revenues and profits from the customer can also increase (Jones et al., 2009). Moreover, a customer's loyalty can also lead to profitability due to decreasing operating costs (Reichheld, 1996). Thus, we hypothesize that: 
$\mathrm{H}_{\mathrm{a}}$ : Satisfaction is positively related to the sales from the KA

$\mathrm{H} 7_{\mathrm{b}}$ : Trust is positively related to the sales from the KA

$\mathrm{H} 7_{\mathrm{c}}$ : Commitment is positively related to the sales from the KA

$\mathrm{H}_{\mathrm{a}}$ : $\quad$ Satisfaction is positively related to the profits from the KA

$\mathrm{H} 8_{\mathrm{b}}$ : Trust is positively related to the profits from the KA

$\mathrm{H} 8_{\mathrm{c}}$ : Commitment is positively related to the profits from the KA

\section{Relational outcomes and dyadic performance}

Cooperation reflects the similar or complementary actions taken by exchange parties in an interdependent relationship derived to achieve mutual or singular outcomes (Anderson \& Narus, 1990). Cooperation implies that both parties understand that they must work together to be successful (Cannon \& Perreault, 1999; Morgan \& Hunt, 1994; Anderson \& Narus, 1990). However, close relationships are not always synonymous with good relationships (Anderson \& Jap, 2005). Excessive cooperation may lead to tensions and/or competition between the two parties (Fang, Chang \& Peng, 2011). The key to maintaining effective cooperation is for both parties to exert a moderate force to accomplish common goals (Fang et al., 2011). However, given that one party often receives its portion of the value earlier, the other party must have enough trust in the relationship to wait for its future reciprocation (Palmatier et al., 2006). Consistently, previous studies have shown that satisfaction, trust and commitment improve the cooperation between the two parties (Anderson \& Narus, 1990; Morgan \& Hunt 1994; Palmatier et al., 2006). Thus, we hypothesize that:

$\mathrm{H} 9_{\mathrm{a}}$ : Satisfaction is positively related to cooperation

$\mathrm{H} 9_{\mathrm{b}}$ : Trust is positively related to cooperation

$\mathrm{H} 9_{\mathrm{c}}$ : Commitment is positively related to cooperation

\section{Mediating effects of information sharing and conflict resolution}

The aforementioned literature speaks more to the implementation of KAM from the supplier perspective. However, literature suggests that the KA participates in the value-creation process (Anderson \& Dubinsky, 2004) and, as such, the relationship between the two parties should be 
considered as a critical aspect of KAM implementation (Storbacka, 2012). From a more tactical perspective, the establishment of relational capabilities is a necessary pre-condition so that KAM can be effectively implemented (Millman \& Wilson, 1999). Implementing KAM, therefore, requires the development of relational capabilities in order to manage the interactions and/or tensions that take place between the two parties.

The previous developed hypotheses have portrayed the positive and direct effects that KAM practices might have on relational outcomes and how these, in turn, might influence performance. However, researchers have suggested that the constructs of information sharing and conflict resolution should link the design of the KAM program and KAM effectiveness (Ryals \& Humphries, 2007; Richards \& Jones, 2009; Millman \& Wilson, 1999). Unfortunately, these intervening links have not been empirically examined. In attempting to rectify this situation, we posit a linkage between KAM practices and relational outcomes through the development of information sharing and conflict resolution. This is clearly an area that requires empirical investigation because, by examining the potential mediating effect of relational capabilities, the findings can add to our understanding of the factors that explain successful KAM relationships. Thus:

$\mathrm{H} 10_{\mathrm{a}}$ : The effect of KAM practices on relational outcomes is mediated by information sharing

H10 : The effect of KAM practices on relational outcomes is mediated by conflict resolution

\section{Method}

\subsection{Sample and Data Collection}

Data were collected by means of a structured questionnaire among suppliers in Greece. The directory of ICAP (a leading business consultant in Greece) served as a sampling frame for our study. ICAP publishes the most comprehensive catalogue of Greek companies across all economic sectors $\left(\mathrm{N}=7,385\right.$ with total sales revenue in excess of $€ 5 \mathrm{~m}^{1}$ at the year of investigation). With the initial sample defined, we have set the following eligibility criteria: the firm had to have launched a formal KAM program no less than 24 months prior to the time of the investigation and, at the same time,

\footnotetext{
${ }^{1}$ A threshold of total sales revenue of $€ 5 \mathrm{~m}$ was employed to eliminate from the population smaller firms that would be unlikely to have neither the knowledge nor the skills or resources to implement a KAM program
} 
score three or better in a five-point "agree/disagree" scale measuring the company's agreement to the following statement: "KAM is the systematic process through which, in this company, we seek to manage our business relations with customers who are of strategic importance to us." Both criteria were assessed through email contact with the marketing/sales manager (depending on the structure each of the sample units employed). The choice to use the mean ("three") of the scale was driven by the need to allow sufficient variance in the responses of the firms who would qualify to participate in the main investigation since many companies employ the term "key account manager" for sales representatives calling on "KAs" (Wengler et al., 2006). Thus, by increasing the variance in the responses it becomes possible to produce a more realistic assessment of the strength of the relationships between the variables under investigation.

At the same time, this process complemented the existing database with updated information on the personal contact details of the participants, helping to improve the response rate in the major study. Consistent with previous studies (e.g. Homburg et al., 2002), we focused on higher-level managers as the most suitable informants (indicatively, depending on the organizational arrangements, the titles of the respondents include key account management director, key account manager marketing director and sales director) as they are more likely to have a more holistic comprehension of the KAM program. At the same time, they are most likely to have a fairly pragmatic picture of the customer's attitudes toward their company as reflected in the company's own management information system records (Crittenden \& Crittenden, 1995). A total of 2,402 companies replied.

Of the 2,402 companies initially included in the sample, 800 qualified to participate and from these 304 actually agreed to do so. For these 304 companies that agreed to participate (effective response rate 38\%), an appointment at the firm's premises was made. An effective sample consists of companies from different sectors-including fast-moving consumer goods; chemical and pharmaceutical products; computers and electronics; banks and insurance; telecommunications; metals; furniture; medical equipment; and professional services - given that cross-sectional samples are likely to enhance the generalizability of the findings (Geyskens, Steenkamp, Scheer \& Kumar, 1996). Table 1 presents the description of our sample. Three weeks after the initial contact, a 
telephone follow-up was run to non-respondents. Early and late respondents were compared to assess non-response bias (Armstrong \& Overton, 1977). A t-test of difference in means on all the constructs of the study showed no significant difference in means between early and late respondents, suggesting thus that non-response bias was not a problem in our study.

\section{PLACE TABLE 1 AROUND HERE}

\subsection{Measures}

The measures used in the study were adopted or adapted where appropriate from existing literature, with the exception of account planning and KAM evaluation where we developed new measures based on literature review. We followed the guidelines suggested by Churchill (1979) and the developed items were submitted to five academics and five managers responsible for managing KA. The participants were asked to check the clarity of each item and whether it reflects the underlying construct. Based on the feedback, some items were revised in order to improve their precision and clarity and the resulting items were included in the survey. Concerning the other KAM practices, KAM esprit de corps and use of teams were measured using the scales of Workman et al. (2003). The scales of top management involvement and KAM activities were adopted from Gounaris and Tzempelikos (2013). Information sharing and conflict resolution were measured using the scales adopted by Heide and John (1992) and Anderson and Narus (1990), respectively. The operationalization of relational outcomes was based on the constructs of satisfaction, trust and commitment and for their measurement we relied on the scales of Cannon and Perreault (1999), Doney and Cannon (1997) and Morgan and Hunt (1994), respectively. A slight modification was made according to the pre-tests in the case of satisfaction. Specifically, the first four items intended to measure the customer's level of satisfaction and happiness with the supplier while the item "The customers are very pleased with what the supplier does for them" was considered to overlap with the remaining four items and it was removed. For the measurement of the dyadic outcome of cooperation we adapted the scale of Cannon and Perrault (1999). Again, a slight modification was made according to the pre-tests to fit the current research context. Specifically, the item "We must work together to be successful" was removed as it was considered rather inapplicable to every KAM relationship. The 
remaining five items in this scale refer to the degree of cooperation between suppliers and KA and, thus, tap the facets of the construct. Finally, the assessment of KA performance relied on the selfevaluation of sales and profits.

A pre-testing of the questionnaire was conducted in two different phases. First, ten experts (five academics and five practitioners) were asked to identify problems with the wording of the questionnaire and to check the face validity of the measures. Then the questionnaire was tested with three academics and ten practitioners from the population under investigation in order to increase content validity and clarity of the measures. Based on the feedback, some items were revised in order to improve their precision and clarity. All the items were measured using a seven-point scale; the scale items are displayed in the Appendix.

\section{Results}

\subsection{Measures Evaluation}

Following standard procedures (Nunnally, 1978; Gerbing \& Anderson, 1988), the reliability and validity of the measures were assessed. The scale properties are provided in Table 2, and the means, standard deviations and correlations among the constructs are shown in Table 3. First, we examined the items by item-total correlations and exploratory factor analysis. Items that exhibited low item-total correlation $(<0.30)$ and low loadings on intended factors $(<0.50)$ were removed.

First, composite reliability for all measures exceeded the threshold value of 0.6 (Bagozzi \& Yi, 1988). Furthermore, for all of the constructs, Cronbach's alphas exceeded the 0.7 threshold (Nunnally, 1978), thus indicating that the measures exhibited good internal consistency. Second, we conducted principal component analysis on each construct to check for unidimensionality. The results reported high loadings on the intended factors, providing support for the unidimensionality of the measures (see Table 2).

PLACE TABLE 2 AROUND HERE

PLACE TABLE 3 AROUND HERE 
Construct validity was assessed by means of Fornell and Larcker's (1981) criteria. In particular, average variance extracted (AVE) in all the measures exceeds 0.50 , providing evidence of convergent validity. Additionally, the AVE for each construct is higher than the squared correlation between that construct and any other construct in the model. Hence, discriminant validity holds for all constructs used in the study.

Moreover, as our study followed a single-informant approach, several procedural remedies were employed against potential problems associated with common-method bias (Podsakoff, MacKenzie, Lee \& Podsakoff, 2003). Common-method bias involves a bias in the responses due to something external to the measures. First, respondents were guaranteed anonymity and confidentiality of the data to reduce evaluation apprehension. Second, clarity of the measurement items was achieved using pre-validated scales and by pre-testing the questionnaire. In addition, we used Harman's singlefactor test (Podsakoff et al., 2003). The first factor accounted for 31 per cent of the variance and no common factor underlying the data was found. To test the robustness of this assertion, we also used confirmatory factor analysis as an additional, more stringent test to Harman's single-factor test. We loaded all items into one confirmatory factor with very poor fit statistics $\left(x^{2}(379)=2783.6, \mathrm{CFI}=0.48\right.$, $\mathrm{NNFI}=0.47, \mathrm{GFI}=0.44, \mathrm{RMSEA}=0.15$ ). Therefore, we can conclude that one latent factor does not account for all marked variables suggesting, thus, that common-method bias appears not to be a problem in this study (Podsakoff et al., 2003). In summary, all measures had satisfactory psychometric properties and suggested that it was appropriate to proceed with the testing of the hypotheses.

\subsection{Results and Discussion}

We used structural equation modelling by means of Amos to test our hypotheses. We report the results of the hypothesis testing in Table 4. Initially, the direct (non-mediated) influence on relational outcomes was assessed by constraining the structural coefficients of the mediation path to zero. The overall-fit measures provide a good fit for the data $\left(x^{2}(364)=914.8, \mathrm{CFI}=0.96 \mathrm{NNFI}=0.95, \mathrm{GFI}=0.94\right.$, RMSEA=0.05). Turning to the results concerning the specific hypotheses, we found that all KAM 
practices are positively related to relational outcomes with the exception of the KAM evaluation that was insignificant to satisfaction. Thus, H1, H2, H3, H4, H5 and H6 are supported.

The results show that relational outcomes positively affect sales and profits from KA. The only exception is the relationship between commitment and profits, which appears to be insignificant. This indicates that a collaborative relationship may not be financially successful, probably due to the high costs associated with the management of the KA. Thus, $\mathrm{H} 7, \mathrm{H} 8_{\mathrm{a}}$ and $\mathrm{H} 8_{\mathrm{b}}$ are supported while we fail to find support for $\mathrm{H} 8_{\mathrm{c}}$.

Finally, trust and commitment are also found to positively influence cooperation $(\beta=0.17$, $p<0.05$ and $\beta=0.24, p<0.01$, respectively) supporting, thus, $\mathrm{H} 9_{\mathrm{b}}$ and $\mathrm{H} 9_{\mathrm{c}}$. Interestingly enough, satisfaction appears to be insignificant of cooperation, thus failing to support $\mathrm{H} 9_{\mathrm{a}}$. This is possibly explained by the fact that firms often perceive the need to maintain a relationship and cooperate with the exchange partner because of the anticipated termination or switching costs associated with leaving (Geyskens et al., 1996).

\section{PLACE TABLE 4 ABOUT HERE}

Next, a rival model excluding information sharing and conflict resolution was tested. The rival model evidenced a rather poor fit $\left(x^{2}(362)=1202.8, \mathrm{CFI}=0.91 \mathrm{NNFI}=0.90, \mathrm{GFI}=0.90, \mathrm{RMSEA}=0.07\right)$. Finally, the conceptualized model including the information sharing and conflict resolution in the mediation path was tested. The model fit was much better $\left(x^{2}(360)=902.4, \mathrm{CFI}=0.96 \mathrm{NNFI}=0.95\right.$, $\mathrm{GFI}=0.95, \mathrm{RMSEA}=0.05$ ). Furthermore, there was an increase in the chi-square values from the direct model $\left(\Delta x^{2}(4)=12, p<0.05\right)$. These findings provide evidence for the hypothesized model supporting mediation hypotheses $\mathrm{H}_{10}$ and $\mathrm{H} 10_{\mathrm{b}}$. As hypothesized, the KAM practices affect the relational outcomes through the development of relational capabilities. This finding is consistent with much of the broader relationship marketing literature that suggests that information sharing and conflict resolution facilitate the implementation of relational strategies either because they result in a constructive resolution of conflicts (Mohr \& Spekman, 1994) or because they help the customer to lower operational costs (Cannon \& Homburg, 2001). 


\section{Implications}

The results of the study make several contributions to the existing KAM literature. One contribution for academics answers the questions of "how" should practitioners expect to benefit from KAM. From the hypotheses tested, the data clearly demonstrate that, in addition to the impact KAM has on sales and profits, the relationship between the supplier and the KA (dyadic performance) also benefits from higher levels of cooperation. However, the positive impact of KAM on performance is not direct as the core elements of what has been termed "relational outcomes" (satisfaction, trust and commitment) mediate the relationship between KAM practices and performance outcomes. Enhancing relational outcomes is, however, a time-consuming process as, for instance, gaining the trust of the customer as well as the customer's commitment in the relationship usually takes considerable time (Palmatier et al., 2006). Thus, the identification of this link helps to confirm but more importantly explain why previous empirical research has suggested that the successful implementation of KAM is indeed a lengthy process (Davies \& Ryals, 2009).

Another, and probably the most notable, contribution for academics comes from the systematization of the practical facets that drive the implementation of KAM. Based on the results of the data analysis, we identify and report six practices of KAM that we find relate to KAM success, namely (1) account planning and selection, (2) top management involvement, (3) KAM esprit de corps, (4) use of teams, (5) KAM activities and (6) KAM evaluation. Our findings and the derived systematization of the KAM practices differ from past research in that we examine the practices in relation to the relational capabilities of information sharing and conflict resolution. We posit that it is the mediation of relational capabilities that actually enables KAM practices to drive KAM effectiveness. Based on our findings, it is clear that to implement KAM successfully, in addition to the organizational fine-tuning that is required, it is also necessary to recognize that customers play a critical role in successfully defining, forming and, possibly, delivering the "product solution" they expect from their suppliers (Anderson \& Dubinsky, 2004). However, as the KA becomes increasingly involved in the development of the supplier's offering, a greater degree of complexity is introduced in the supplier's systems and organization (Vargo \& Lusch, 2004). In fact, one good reason why 
organizational changes are required in the first place is to cope with this complexity and facilitate the supplier's responsiveness to the KA requirements. Having said this, as KA managers span the boundaries between the supplier and the customer, an essential task they have is to smooth the interaction of the two organizations through the sharing of information that improves each party's understanding of the other side and to resolve conflicts effectively, if and when they emerge. At the same time, KA managers need to coordinate the supplier's response to the KA's requirements for customized solutions in a timely fashion.

Stemming from the latter, this study has significant implications for the implementation of KAM, and consequently for practitioners. According to the results, account planning and selection, KAM activities, the use of teams, KAM evaluation, KAM esprit de corps and the greater involvement of top management are all practices that influence the outcome of the KAM program through customer satisfaction, trust and commitment to the supplier.

However, by looking closely at the regression weights presented in Table 4, it becomes evident that KAM activities toward customization and top management involvement are the two most powerful drivers of the relational outcomes. So, ensuring that the supplier either reactively or proactively tailors its offering to meet the KA's unique requirements is one key facet of a successful KAM program. In doing so, although monitoring the costs associated with customization is common sense, this cost should not impede suppliers from tailoring their product to the KA's needs as customization gears the success of the KAM program. Likewise, top management need to get actively involved with decision making (at a strategic level) and provide the KA managers with the necessary authority, resources and coaching to enable them to produce customized solutions for the KA.

Developing a company-wide esprit de corps around the significance of the KAM program is also helpful (the third most important driver), especially as the relationship between the two companies progresses into higher levels of collaboration (Woodburn \& McDonald, 2011) where open communication channels between a larger number of managers from both organizations allow even quicker response to the needs of the customer. At these stages of the relationship it is essential that every contact employee or manager of the supplier demonstrates the necessary awareness of and 
attentiveness to the requirements of the KA's personnel every time they are in contact (Guesalaga \& Johnston, 2010). Albeit not within the scope of the present study, a strong esprit de corps may also be particularly useful for large suppliers who serve multinational KAs through blanket contracts. In such situations the criticalness of the KA may not be equally perceived across all the different offices or service points of the supplier.

As far as the relational capabilities are concerned, while information sharing is important to generate trust and thus needs to be encouraged and facilitated by the supplier's systems and managers' conduct, resolving conflicts effectively is the crucial characteristic of successful KAM practice. The co-creative nature of the value the KAM program produces for the KA (Storbacka, 2012) frequently feeds the relationship between the two companies with reasons for tension and often conflict. Our findings clearly demonstrate the significance of developing and sustaining conflict-resolution mechanisms capable of handling different types of conflict that may arise between the two organizations. Information-sharing practices can actually prove to be very helpful in this respect by allowing integrative mechanisms to conflict resolution and to reach joint benefits and attain "winwin" goals (Mohr \& Spekman, 1994). Norms for joint decision making and goal setting based on openly communicated facts about such issues as monetary costs, time and/or technology and capacity constraints can thus prove invaluable assets that suppliers should readily use in resolving conflicts that may arise with a KA. Having said this, suppliers need to be mindful of the high risk associated with conflict-resolution mechanisms of an integrative nature (Koza \& Dant, 2007) and use them cautiously and progressively as the relationship with the KA matures.

\section{Limitations and Future Research}

Notwithstanding the contribution this study makes, certain limitations are worth noting, especially as at the same time they open very interesting directions for future research. For instance, the list of KAM practices is not exhaustive and the context of the KAM initiative has also not been addressed in its entirety. Competitive intensity and the idiosyncratic characteristics of the customer are some of the variables this study has not considered. Likewise, the globalization of economic 
activity is resulting in higher trade concentration with suppliers serving international KAs. To address such issues would increase the complexity of the research design. In the lack of relevant empirical research, the choice for a simpler design that would allow an initial mapping of the KAM actions leading to superior performance prevailed. Nonetheless, with this objective achieved, future research can now attempt more complex designs that will address such issues and will complete further scholarly understanding of practices explaining KAM performance under different contextual conditions. At the same time, future research can and should look at the actual implementation of the practices identified in this study. For instance, what actions are more effective in developing a strong esprit de corps? What information is most appropriate when planning for KAs? What are the most important KPIs to track when monitoring the implementation of a KAM initiative? Answering such questions will provide an invaluable insight for practitioners, allowing scholars to provide truly useful guides for effectively managing the relationship with KAs on the actual implementation level. Casestudy research would be most appropriate for this kind of investigation.

A second limitation involves the key informant technique from the supplier's side. Although common-method bias was not diagnosed, the risk remains as the technique represents a barrier to the comprehensive evaluation of relational outcomes (satisfaction, trust, commitment) and dyadic performance (cooperation). Although choosing the appropriate key informant can help improve the accuracy of the data, relational variables represent, by definition, both sides of the buyer/seller dyad. Therefore, relying on the supplier's side alone cannot capture such constructs in full. Again, a more complex research design entailing multiple informants would allow not only for data cross-validation but, more importantly, could offer a more comprehensive view enabling the identification of potential perceptive gaps between the supplier and the KA. Such designs can confidently rely upon the findings of the present investigation and produce valuable empirical insights in the future. In addition, the study focuses on the portfolio of KA. A dyad analysis will offer the opportunity to examine individual relationships, providing thus deeper insights in the understanding of KAM relationships

Finally, this study focuses on KAM effectiveness at account level. Although KAM affects performance at the organizational level (Homburg et al., 2002; Workman et al., 2003), other factors, 
such as superior products and/or services, emerging customers' needs or even smaller, on average, customers, can also affect organizational performance (Homburg et al., 2002). Hence, future research attempting to examine KAM with regard to other drivers of performance at the company level will add to our understanding of the antecedents to performance in business markets.

\section{References}

Abratt, R. \& Kelly, P.M. (2002). Customer-supplier partnerships. Perceptions of a successful key account management program. Industrial Marketing Management, 31, 467-476.

Aijo, T. S. (1996). The theoretical and philosophical underpinnings of relationship marketing: Environmental factors behind the changing marketing paradigm. European Journal of Marketing, 30(2), 8-18.

Alejandro, T. B., Souza, D. V., Boles, J. S., Helena, A., Ribeiro, P. \& Monteiro, P. R. R. (2011). The outcome of company and account manager relationship quality on loyalty, relationship value and performance. Industrial Marketing Management, 40(1), 36-43.

Anderson, E. \& Jap, S. D. (2005). The dark side of close relationships. MIT Sloan Management Review, 46(3), 75-82.

Anderson, E. \& Weitz, B. (1992 February). The use of pledges to build and sustain commitment in distribution channels. Journal of Marketing Research, 29, 18-34.

Anderson, J.C. \& Narus, J.A. (1990 January). A model of distributor firm and manufacturer firm working partnerships. Journal of Marketing, 54, 42-58.

Anderson, R. E. \& Dubinsky, A. J. (2004). Personal Selling: Achieving Customer Satisfaction and Loyalty. Boston, MA: Houghton Mifflin.

Armstrong, J. S. \& Overton, T. S. (1977 August). Estimating nonresponse bias in mail surveys. Journal of Marketing Research, 14, 396-402.

Arnett, D. B., Macy, B. A. \& Wilcox, J. B. (2005). The role of core selling teams in supplier-buyer relationships. Journal of Personal Selling \& Sales Management, 25(1), 27-42. 
Bagozzi, R. P. \& Yi, Y. (1988 Spring). On the evaluation of structural equation models. Journal of the Academy of Marketing Science, 16, 74-94.

Barney, J., Wright, M. \& Ketchen, D. J. (2001). The resource-based view of the firm: Ten years after 1991. Journal of Management, 27(6), 625-641.

Cannon, J. P. \& Homburg, C. (2001). Buyer-supplier relationships and customer firm costs. Journal of Marketing, 65(1), 29-43.

Cannon, J.P. \& Perreault Jr., W.D. (1999 November). Buyer-seller relationships in business markets. Journal of Marketing Research, 36, 439-460.

Carpenter, M. A., Geletkanycz, M. A. \& Sanders, W. G. (2004). Upper echelons research revisited: Antecedents, elements, and consequences of top management team composition. Journal of Management, 30(6), 749-778.

Churchill Jr., G. A. (1979 February). A paradigm for developing better measures of marketing constructs. Journal of Marketing Research, 16, 64-73.

Crittenden, V. L. \& Crittenden, W. F. (1995). Examining the impact of manufacturing and marketing capacity decisions on firm profitability. International Journal of Production Economics, 40(1), $57-72$.

Crosby, L. A., Evans, K. A. \& Cowles, D. (1990). Relationship quality in services selling: An interpersonal influence perspective. Journal of marketing, 54(3).

Davies, I. A. \& Ryals, L. J. (2009). Attitudes and behaviours of key account managers: Are they really any different to senior sales professionals? Industrial Marketing Management, 42(6), 919-931.

Davies, I. A. \& Ryals, L. J. (2013). A stage model for transitioning to KAM. Journal of Marketing Management, 25(9-10), 1027-1048.

Day, G. (2000 Winter). Managing market relationships. Journal of the Academy of Marketing Science, $28,24-30$.

Doney, P.M. \& Cannon, J.P. (1997 April). An examination of the nature of trust in buyer-seller relationships. Journal of Marketing, 61, 35-51. 
Fang, S-R., Chang, Y-S. \& Peng, Y-C. (2011). Dark side of relationships: A tensions-based view. Industrial Marketing Management, 40, 774-784.

Fisher, R. J., Maltz, E. \& Jaworski, G. J. (1997). Enhancing communication between marketing and engineering: The moderating role of relative functional identification. Journal of Marketing, 61, $54-70$.

Fornell, C. \& Larcker, D.F. (1981 February). Evaluating structural equation models with unobservable variables and measurement error. Journal of Marketing Research, 18, 39-50.

Geiger, S. \& Turley, D. (2005). Personal selling as a knowledge-based activity: Communities of practice in the sales force. Irish Journal of Management, 26(1), 61-70.

Gerbing, D. \& Anderson, J. (1988 May). An updated paradigm for scale development incorporating unidimensionality and its assessment. Journal of Marketing Research, 25, 186-192.

Geyskens, I., Steenkamp, J. \& Kumar, N. (1999 May). A meta-analysis of satisfaction in marketing channel relationships. Journal of Marketing Research, 36, 223-238.

Geyskens, I., Steenkamp, J-B., Scheer, L.K. \& Kumar, N. (1996). The effects of trust and interdependence on relationship commitment: A transatlantic study. International Journal of Research in Marketing, 13(4), 303-317.

Gounaris, S. \& Tzempelikos, N. (2013). Key account management orientation and its implications: A conceptual and empirical examination. Journal of Business-to-Business Marketing, 20(1), 3355.

Guenzi, P., Georges, L. \& Pardo, C. (2009). The impact of strategic account managers' behaviors on relational outcomes: An empirical study. Industrial Marketing Management, 38, 300-311.

Guenzi, P., Pardo, C. \& Georges, L. (2007). Relational selling strategy and key account managers' relational behaviors: An exploratory study. Industrial Marketing Management, 36, 121-133.

Guesalaga, R. (2014). Top management involvement with key accounts: The concept, its dimensions, and strategic outcomes. Industrial Marketing Management (forthcoming).

Guesalaga, R. \& Johnston, W. (2010). What's next in key account management research? Building the bridge between the academic literature and the practitioners' priorities. Industrial Marketing Management, 39(7), 1063-1068. 
Harvey, M., Novisevic, M. M., Hench, T. \& Myers, M. B. (2003). Global account management: A supply-side managerial view, Industrial Marketing Management, 32(7), 563-571.

Heide, J. B. \& John, G. (1992 April). Do norms matter in marketing relationships? Journal of Marketing, 56, 32-44.

Homburg, C. \& Stock, R. M. (2004 Spring). The link between salespeople's job satisfaction and customer satisfaction in a business-to-business context: A dyadic analysis. Journal of the Academy of Marketing Science, 32, 144-158.

Homburg, C., Workman, Jr., J. P. \& Jensen, O. (2000). Fundamental changes in marketing organization: The movement toward a customer-focused organizational structure. Journal of the Academy of Marketing Science, 28(4), 459-478.

Homburg, C., Workman Jr., J. P. \& Jensen, O. (2002 April). A configurational perspective of key account management. Journal of Marketing, 66, 38-60.

Ivens, B. S. \& Pardo, C. (2007). Are key account relationships different? Empirical results on supplier strategies and customer reactions. Industrial Marketing Management, 36(4), 470-482.

Ivens, B. S. \& Pardo, C. (2008). Key account management in business markets: An empirical test of common assumptions. Journal of Business \& Industrial Marketing, 23(5), 301-310.

Jaworski, B. J. \& Kohli, A. K. (1993). Market orientation: Antecedents and consequences. Journal of Marketing, 53-70.

Jones, E., Richards, K. A., Halstead, D. \& Fu, F. Q. (2009). Developing a strategic framework of key account performance. Journal of Strategic Marketing, 17(3), 221-235.

Kirca, A. H., Jayachandran, S. \& Bearden, W. O. (2005). Market orientation: A meta-analytic review and assessment of its antecedents and impact on performance. Journal of Marketing, 69(2), 2441.

Koza, K. L. \& Dant, R. P. (2007). Effects of relationship climate, control mechanism, and communications on conflict resolution behavior and performance outcomes. Journal of Retailing, 83(3), 279-296.

Millman, T. \& Wilson, K. (1995). From key account selling to key account management. Journal of Marketing Practice: Applied Marketing Science, 1(1), 9-21. 
Millman, T. \& Wilson, K. (1999). Process issues in key account management: Underpinning the customer-facing organization. Journal of Business \& Industrial Marketing, 14(4), 328-337.

Mohr, J. \& Spekman, R. (1994). Characteristics of partnership success: Partnership attributes, communication behavior, and conflict resolution. Strategic Management Journal, 15(2), $135-152$.

Moon, M. A. \& Armstrong, G. M. (1994). Selling teams: A conceptual framework and research agenda. Journal of Personal Selling \& Sales Management, 14(1), 17-30.

Moorman, C., Zaltman, G. \& Deshpandé, R. (1992 August). Relationships between providers and users of market research: The dynamics of trust within and between organizations. Journal of Marketing Research, 29, 314-328.

Morgan, R. M. \& Hunt, S.D. (1994 July). The commitment-trust theory of relationship marketing. Journal of Marketing, 58, 20-38.

Nätti, S., Halinen, A. \& Hanttu, N. (2006). Customer knowledge transfer and key account management in professional service organizations. International Journal of Service Industry Management, 17(4), 304-319.

Nunnally, J. C. (1978). Psychometric Theory. 2nd ed., New York: McGraw-Hill.

Ojasalo, J. (2001). Key account management at company and individual levels in business-to-business relationships. Journal of Business \& Industrial Marketing, 16(3), 199-220.

Palmatier, R. W., Dant, R. P., Grewal, D. \& Evans, K. R. (2006 October). Factors influencing the effectiveness of relationship marketing: A meta-analysis. Journal of Marketing, 70, 136-153.

Pardo, C., Henneberg, S. C., Mouzas, S. \& Naudè, P. (2006). Unpicking the meaning of value in key account management. European Journal of Marketing, 40(11/12), 1360-1374.

Podsakoff, P. M., MacKenzie, S. M., Lee, J. \& Podsakoff, N. P. (2003). Common-method variance in behavioral research: A critical review of the literature and recommended remedies. Journal of Applied Psychology, 88, 879-903.

Reichheld, F. F. (1996). The Loyalty Effect: The Hidden Force Behind Growth, Profits, and Lasting Value. Boston, MA: Harvard Business School Press. 
Richards, K. A. \& Jones, E. (2009). Key account management: Adding elements of account fit to integrative theoretical framework. Journal of Personal Selling \& Sales Management, 29(4), $305-320$.

Ryals, L. J. \& Holt, S. (2007). Creating and capturing value in KAM relationships. Journal of Strategic Marketing, 15(4), 403-420.

Ryals, L. J. \& Humphries, A. S. (2007). managing key business-to-business relationships: What marketing can learn from supply chain management. Journal of Service Research, 9(4), 312326.

Ryals, L. J. \& McDonald, M. (2008). Key Account Plans: The Practitioner's Guide to Profitable Planning. Oxford: Elsevier.

Salojärvi, H. \& Saarenketo, S. (2013). The effect of teams on customer knowledge processing, esprit de corps and account performance in international key account management. European Journal of Marketing, 47(5/6), 987-1005.

Salojärvi, H., Sainio, L-M. \& Tarkiainen, A. (2010). Organizational factors enhancing customer knowledge utilization in the management of key account relationships. Industrial Marketing Management, 39(8), 1395-1402.

Shapiro, B. P. \& Moriarty, R. T. (1984). Support systems for national account management programs. Marketing Science Institute Working Paper No. 84-102. Cambridge, MA: Marketing Science Institute.

Srivastava, R. K., Shervani, T. A. \& Fahey, L. (1998). Market-based assets and shareholder value: A framework for analysis. Journal of Marketing, 62(1), 2-18.

Storbacka, K. (2012). Strategic account management programs: Alignment of design elements and management practices. Journal of Business \& Industrial Marketing, 27(4), 259-274.

Storbacka, K. \& Nenonen, S. (2009). Customer relationships and the heterogeneity of firm performance. Journal of Business \& Industrial Marketing, 24(5/6), 360-372.

Vargo, S. L. \& Lusch, R. F. (2004). Evolving to a new dominant logic for marketing. Journal of Marketing, 68(1), 1-17. 
Wengler, S., Ehret, M. \& Saab, S. (2006). Implementation of key account management: Who, why, and how? An exploratory study on the current implementation of key account management programs. Industrial Marketing Management, 35(1), 103-112.

Wernerfelt, B. (1984). A resource based view of the firm. Strategic management journal, 5(2), 171180.

Woodburn, D. \& McDonald, M. (2011). Key Account Management: The Definitive Guide. 3rd ed., Chichester: John Wiley \& Sons

Workman, J.P., Homburg, C. \& Jensen, O. (2003). Intraorganizational determinants of key account management effectiveness. Journal of the Academy of Marketing Science, 31(1), 3-21.

Zupancic, D. (2008). Towards an integrated framework of key account management. Journal of Business \& Industrial Marketing, 23(5), 323-331. 


\begin{tabular}{|c|c|c|c|}
\hline Construct & Items & $\mathrm{M} / \mathrm{SD}$ & $\begin{array}{l}\text { Item } \\
\text { loading }\end{array}$ \\
\hline \multicolumn{4}{|l|}{ KAM practices } \\
\hline \multirow[t]{4}{*}{$\begin{array}{l}\text { KAM planning } \\
\text { and selection }\end{array}$} & $\begin{array}{l}\text { The attractiveness of different accounts is assessed against specific criteria } \\
\text { that reflect our strategic goals. }\end{array}$ & $4.55 / 1.19$ & 0.81 \\
\hline & $\begin{array}{l}\text { We scrutinize market intelligence and internal records to assess how specific } \\
\text { accounts fit with our own strategic objectives. }\end{array}$ & $4.35 / 1.32$ & 0.79 \\
\hline & $\begin{array}{l}\text { We carefully plan our KAM program to ensure a balance between available } \\
\text { resources and the number of key accounts we can realistically target. }\end{array}$ & $4.39 / 1.26$ & 0.76 \\
\hline & $\begin{array}{l}\text { When we design and launch an initiative for a KA we always plan ahead and } \\
\text { consider the implications for our company in the long run. }\end{array}$ & $4.24 / 1.21$ & 0.73 \\
\hline \multirow{5}{*}{$\begin{array}{l}\text { Top } \\
\text { management } \\
\text { involvement }^{\mathrm{a}}\end{array}$} & $\begin{array}{l}\text { Top management allocates the required resources (money, time, personnel) } \\
\text { for the KAM function. }\end{array}$ & $5.14 / 1.09$ & 0.75 \\
\hline & $\begin{array}{l}\text { Top management systematically monitors the KAM function within the } \\
\text { company. }\end{array}$ & $5.72 / 1.05$ & 0.77 \\
\hline & $\begin{array}{l}\text { Top management intervenes, when necessary, in order to find solutions to } \\
\text { problems that our KAs face. }\end{array}$ & $5.46 / 1.09$ & 0.83 \\
\hline & $\begin{array}{l}\text { Top management actively participates in the designing of activities regarding } \\
\text { our KAs. }\end{array}$ & $5.59 / 1.07$ & 0.82 \\
\hline & $\begin{array}{l}\text { Top management compensates/ rewards the actions and initiatives that lead to } \\
\text { the development of the relationships with our KAs. }\end{array}$ & $4.88 / 1.28$ & 0.73 \\
\hline \multirow[t]{4}{*}{$\begin{array}{l}\text { KAM esprit de } \\
\operatorname{corps}^{\mathrm{a}}\end{array}$} & $\begin{array}{l}\text { "People involved in the management of a key account..." } \\
\text { are genuinely concerned about the needs and problems of each other. }\end{array}$ & $5.21 / 1.13$ & 0.87 \\
\hline & have a team spirit that pervades all ranks involved. & $5.38 / 1.11$ & 0.89 \\
\hline & feel like they are part of a big family. & $5.14 / 1.19$ & 0.85 \\
\hline & $\begin{array}{l}\text { (view themselves as independent individuals who have to tolerate others } \\
\text { around them). (R) }\end{array}$ & $4.76 / 1.26$ & 0.74 \\
\hline \multirow[t]{3}{*}{ Use of teams ${ }^{\mathrm{a}}$} & $\begin{array}{l}\text { When there is a problem related to our KA relationships, a group is brought in } \\
\text { to solve it. }\end{array}$ & $5.20 / 1.37$ & 0.87 \\
\hline & KA-related decisions are made by teams. & $5.04 / 1.47$ & 0.89 \\
\hline & We have teams that plan and coordinate activities for KAs. & $4.73 / 1.54$ & 0.85 \\
\hline \multirow{6}{*}{$\begin{array}{l}\text { KAM } \\
\text { activities }^{\text {a }}\end{array}$} & We adapt our products/services according to our KAs' needs. & $4.92 / 1.33$ & 0.66 \\
\hline & We respond immediately to our KAs' problems. & $5.78 / 0.99$ & 0.77 \\
\hline & We adapt the level of our service quality according to our KAs' needs. & $5.35 / 1.05$ & 0.77 \\
\hline & (We adapt our pricing policy to our KAs.) & $4.95 / 1.87$ & 0.41 \\
\hline & We adapt our internal processes in order to meet our KAs' needs. & $4.87 / 1.26$ & 0.73 \\
\hline & We frequent and informally communicate with our KAs. & $6.09 / 0.91$ & 0.65 \\
\hline \multirow{3}{*}{$\begin{array}{l}\text { KAM } \\
\text { evaluation }^{\mathrm{a}}\end{array}$} & We systematically assess the financial outcomes of our KAM relationships. & $5.32 / 0.86$ & 0.83 \\
\hline & We systematically assess the relational outcomes of our KAM relationships. & $5.06 / 1.18$ & 0.75 \\
\hline & We frequently assess the effectiveness of our KAM relationships. & $5.26 / 1.09$ & 0.82 \\
\hline \multicolumn{4}{|c|}{ Relational capabilities } \\
\hline \multirow[t]{4}{*}{$\begin{array}{l}\text { Information } \\
\text { sharing }^{\mathrm{a}}\end{array}$} & $\begin{array}{l}\text { In this relationship, it is expected that any information that might help the } \\
\text { other party will be provided to them. }\end{array}$ & $4.88 / 1.40$ & 0.84 \\
\hline & Exchange of information in this relationship takes place frequently. & $4.84 / 1.41$ & 0.86 \\
\hline & $\begin{array}{l}\text { It is expected that the parties will provide proprietary information if it can } \\
\text { help the other party. }\end{array}$ & $4.36 / 1.55$ & 0.82 \\
\hline & $\begin{array}{l}\text { It is expected that we keep each other informed about events or changes that } \\
\text { may affect the other party. }\end{array}$ & $5.03 / 1.31$ & 0.82 \\
\hline
\end{tabular}




\begin{tabular}{|c|c|c|c|}
\hline \multirow[t]{4}{*}{$\begin{array}{l}\text { Conflict } \\
\text { resolution }^{\mathrm{a}}\end{array}$} & $\begin{array}{l}\text { Most disagreements we have are resolved productively, generating greater } \\
\text { understanding between us. }\end{array}$ & $5.32 / 1.20$ & 0.80 \\
\hline & $\begin{array}{l}\text { The way we manage conflict or disputes tends to create stress, frustration or } \\
\text { ill-feelings in our relationship. (R) }\end{array}$ & $5.38 / 1.36$ & 0.69 \\
\hline & $\begin{array}{l}\text { Problems that arise in this relationship tend to be handled jointly, not } \\
\text { individually. }\end{array}$ & $5.01 / 1.18$ & 0.74 \\
\hline & Disputes that arise between us are generally not worked out very well. (R) & $5.56 / 1.30$ & 0.79 \\
\hline \multicolumn{4}{|c|}{ Relational outcomes } \\
\hline \multirow[t]{4}{*}{ Satisfaction $^{\mathrm{a}}$} & Our KAs are very satisfied with us. & $5.51 / 0.88$ & 0.79 \\
\hline & They are very pleasant with what we do for them. & $6.19 / 1.02$ & 0.80 \\
\hline & If they had to do it all over again, they would still choose us as supplier. & $5.43 / 0.92$ & 0.65 \\
\hline & (They have regretted their decision to cooperate with us.) (R) & $5.77 / 0.89$ & 0.54 \\
\hline \multirow[t]{5}{*}{ Trust $^{\mathrm{a}}$} & They are convinced that we keep our promises to them. & $6.04 / .88$ & 0.77 \\
\hline & They believe that we are genuinely concerned about their business success. & $5.95 / .83$ & 0.82 \\
\hline & They believe the information that we give them. & $5.56 / 1.00$ & 0.79 \\
\hline & They believe that we keep their best interest in mind. & $5.63 / 1.04$ & 0.85 \\
\hline & They consider us trustworthy. & $6.28 / 0.80$ & 0.77 \\
\hline \multirow[t]{4}{*}{ Commitment $^{\mathrm{a}}$} & $\begin{array}{l}\text { "Our relationship with KAs..." } \\
\text { is something that they are very committed to. }\end{array}$ & $4.77 / 1.19$ & 0.81 \\
\hline & is very important to them. & $5.29 / 1.08$ & 0.87 \\
\hline & is considered deserving of their maximum effort to maintain. & $5.59 / 0.93$ & 0.91 \\
\hline & is something that they intend to maintain indefinitely. & $5.48 / 1.00$ & 0.86 \\
\hline \multicolumn{4}{|c|}{ Dyadic performance } \\
\hline \multirow[t]{5}{*}{ Cooperation $^{\mathrm{a}}$} & (No matter who is at fault, problems are joint responsibilities.) & $5.06 / 1.27$ & 0.54 \\
\hline & Both sides are concerned about the other's profitability. & $4.53 / 1.48$ & 0.72 \\
\hline & One party will not take advantage of a strong bargaining position. & $3.81 / 1.46$ & 0.71 \\
\hline & Both sides are willing to cooperate. & $5.66 / 1.01$ & 0.72 \\
\hline & We do not mind owing each other favors. & $4.36 / 1.55$ & 0.57 \\
\hline \multicolumn{4}{|c|}{ Financial performance } \\
\hline \multirow[t]{2}{*}{$\begin{array}{l}\text { Indicators of } \\
\text { performance }^{b}\end{array}$} & $\begin{array}{l}\text { "Relative to your objectives, how has your company over the last } 3 \text { years, } \\
\text { performed with KAs with respect to..." } \\
\text { achieving sales. }\end{array}$ & $5.54 / 1.01$ & 0.92 \\
\hline & achieving profits. & $5.29 / 1.16$ & 0.92 \\
\hline
\end{tabular}

\footnotetext{
${ }^{a}$ Seven-point scale with anchors $1=$ totally disagree and $7=$ totally agree

${ }^{\mathrm{b}}$ Seven-point scale with anchors $1=$ much worse and $7=$ much better

Note: Scale items not retained are indicated in parentheses. (R) denotes a reverse-coded item
} 
Table 1: Sample description

\begin{tabular}{|l|c|c|}
\hline & & Total $(\mathrm{n}=304)$ \\
\hline Industry & Food and packaged goods & $33.9 \%$ \\
& Computer and electronics & $14.1 \%$ \\
& Chemical and pharmaceutical products & $10.9 \%$ \\
& Furniture & $7.9 \%$ \\
& Banks and insurance & $6.6 \%$ \\
& Metals & $8.6 \%$ \\
& Professional services & $6.3 \%$ \\
& Medical equipment & $4.6 \%$ \\
& Telecommunications & $5.3 \%$ \\
& Other industrial products & $2.0 \%$ \\
& & \\
& $<6$ million & $14.9 \%$ \\
& 6,1 million -10 million & $11.9 \%$ \\
& 10,1 million -15 million & $11.3 \%$ \\
& 15,1 million -20 million & $7.3 \%$ \\
& 20,1 million -30 million & $7.3 \%$ \\
& 30,1 million - 50 million & $12.6 \%$ \\
& $>50$ million & $34.8 \%$ \\
\hline
\end{tabular}


Table 2: Measures properties

\begin{tabular}{|c|c|c|c|c|c|c|c|c|c|}
\hline & Construct (number of items ${ }^{\mathrm{a}}$ ) & Mean & $\begin{array}{l}\text { Standard } \\
\text { Deviation }\end{array}$ & $\begin{array}{l}\text { Cronbach } \\
\text { Alpha b }\end{array}$ & $\begin{array}{l}\text { Item-total } \\
\text { correlation }\end{array}$ & $\begin{array}{l}\text { Standardiz } \\
\text { ed factor } \\
\text { loading }\end{array}$ & $\begin{array}{l}\text { Composite } \\
\text { Reliability }^{c}\end{array}$ & $\begin{array}{l}\text { Average } \\
\text { Variance } \\
\text { Extracted }^{\mathrm{d}}\end{array}$ & $\begin{array}{l}\text { Squared } \\
\text { correlation }\end{array}$ \\
\hline \multirow[t]{6}{*}{ KAM practices } & Account planning and selection (4) & 4.38 & 1.25 & 0.80 & $.61-.72$ & $.73-.81$ & 0.82 & 0.54 & $.012-.435$ \\
\hline & KAM esprit de corps (4) & 5.12 & 1.17 & 0.88 & $.63-.78$ & $.74-.89$ & 0.90 & 0.65 & $.018-.498$ \\
\hline & Use of teams (3) & 4.99 & 1.46 & 0.84 & $.67-.74$ & $.85-.89$ & 0.87 & 0.64 & $.014-.313$ \\
\hline & Top management involvement (5) & 5.36 & 0.87 & 0.84 & $.58-.71$ & $.73-.83$ & 0.87 & 0.52 & $.017-.465$ \\
\hline & KAM activities (6) & 5.40 & 0.79 & 0.75 & $.45-.57$ & $.65-.77$ & 0.76 & 0.51 & $.024-.416$ \\
\hline & KAM evaluation (3) & 5.21 & 1.04 & 0.79 & $.53-.72$ & $.75-.83$ & 0.80 & 0.56 & $.016-.353$ \\
\hline \multirow{2}{*}{$\begin{array}{l}\text { Relational } \\
\text { capabilities }\end{array}$} & Information sharing (4) & 4.78 & 1.18 & 0.85 & $.67-.72$ & $.82-.86$ & 0.86 & 0.59 & $.020-.180$ \\
\hline & Conflict resolution (4) & 5.32 & 0.95 & 0.75 & $.48-.60$ & $.69-.80$ & 0.76 & 0.52 & $.019-.430$ \\
\hline \multirow{3}{*}{$\begin{array}{l}\text { Relational } \\
\text { outcomes }\end{array}$} & Satisfaction (4) & 5.57 & 0.77 & 0.83 & $.60-.73$ & $.81-.89$ & 0.86 & 0.63 & $.018-.506$ \\
\hline & Trust (5) & 5.89 & 0.73 & 0.86 & $.63-.75$ & $.77-.85$ & 0.88 & 0.54 & $.012-.506$ \\
\hline & Commitment (5) & 5.28 & 0.90 & 0.88 & $.67-.81$ & $.81-.91$ & 0.92 & 0.66 & $.014-.425$ \\
\hline $\begin{array}{l}\text { Dyadic } \\
\text { performance }\end{array}$ & Cooperation (5) & 4.75 & 0.97 & 0.73 & $.46-.60$ & $.68-.80$ & 0.75 & 0.51 & $.022-.430$ \\
\hline \multirow{2}{*}{$\begin{array}{l}\text { Financial } \\
\text { performance }\end{array}$} & Sales (1) & 5.54 & 1.01 & & & & & & \\
\hline & Profits (1) & 5.29 & 1.16 & & & & & & \\
\hline
\end{tabular}

${ }^{a}$ Items with item-total correlations less than .30 and factor loadings less than .50 have been omitted

${ }^{\mathrm{b}}$ Reports coefficient alpha (if more than one item)

${ }^{\mathrm{c}}$ Reports composite reliability (if more than two items)

d AVE is reported when there are more than two items 
Table 3: Means, standard deviations and correlations

\begin{tabular}{|c|c|c|c|c|c|c|c|c|c|c|c|c|c|c|c|c|}
\hline & Mean & S.D & (1) & (2) & (3) & (4) & $(5)$ & $(6)$ & (7) & $(8)$ & (9) & $(10)$ & $(11)$ & $(12)$ & (13) & (14) \\
\hline Account planning and selection (1) & 4.38 & 1.25 & 1 & & & & & & & & & & & & & \\
\hline KAM esprit de corps (2) & 5.12 & 1.17 & $.51^{* *}$ & 1 & & & & & & & & & & & & \\
\hline Use of teams (3) & 4.99 & 1.46 & $.41 * *$ & $.42 * *$ & 1 & & & & & & & & & & & \\
\hline Top management involvement (4) & 5.36 & 0.87 & $.47 * *$ & $.53 * *$ & $.50 * *$ & 1 & & & & & & & & & & \\
\hline KAM activities (5) & 5.40 & 0.79 & $.48^{* *}$ & $.57 * *$ & $.46^{* *}$ & $.64 * *$ & 1 & & & & & & & & & \\
\hline KAM evaluation (6) & 5.21 & 1.04 & $.55^{* *}$ & $.39 * *$ & $38^{* *}$ & $.53 * *$ & $.51 * *$ & 1 & & & & & & & & \\
\hline Information sharing (7) & 4.78 & 1.18 & $.18^{* *}$ & $.16^{* *}$ & $.25^{* *}$ & $.31 * *$ & $.29 * *$ & $.21 * *$ & 1 & & & & & & & \\
\hline Conflict resolution (8) & 5.32 & 0.95 & $.29 * *$ & $.34 * *$ & $.32 * *$ & $.42 * *$ & $38 * *$ & $.19 * *$ & $.28 * *$ & 1 & & & & & & \\
\hline Satisfaction (9) & 5.57 & 0.77 & $.32 * *$ & $.41 * *$ & $.33^{* *}$ & $.52 * *$ & $51 * *$ & $.36^{* *}$ & $.28 * *$ & $.52 * *$ & 1 & & & & & \\
\hline Trust (10) & 5.89 & 0.73 & $.36^{* *}$ & $.39 * *$ & $.36^{* *}$ & $.46^{* *}$ & $48 * *$ & $.33^{* *}$ & $.32 * *$ & $.53 * *$ & $.71 * *$ & 1 & & & & \\
\hline Commitment (11) & 5.28 & 0.90 & $.37 * *$ & $.34 * *$ & $.36^{* *}$ & $.45^{* *}$ & $41 * *$ & $.35^{* *}$ & $.30 * *$ & $.48 * *$ & $.61 * *$ & $.65^{* *}$ & 1 & & & \\
\hline Sales (12) & 5.54 & 1.01 & $.32 * *$ & $.28 * *$ & $.26^{* *}$ & $.31^{* *}$ & $27 * *$ & $.29 * *$ & $.16^{* *}$ & $.17 * *$ & $.35^{* *}$ & $.31 * *$ & $.27 * *$ & 1 & & \\
\hline Profits (13) & 5.29 & 1.16 & $.21^{* *}$ & $.19 * *$ & $.16^{* *}$ & $.22 * *$ & $21 * *$ & $.24 * *$ & $.12 *$ & .10 & $.30 * *$ & $.28 * *$ & $.24 * *$ & $.69 * *$ & 1 & \\
\hline Cooperation (14) & 4.75 & 0.97 & $.22 * *$ & $.31 * *$ & $.33 * *$ & $.48^{* *}$ & $43 * *$ & $.38 * *$ & $.43 * *$ & $.66^{* *}$ & $.49 * *$ & $.49 * *$ & $.48 * *$ & $.15^{* *}$ & $.17 * *$ & 1 \\
\hline
\end{tabular}

$*_{p}<0.05 . \quad * *_{p}<0.01$ 


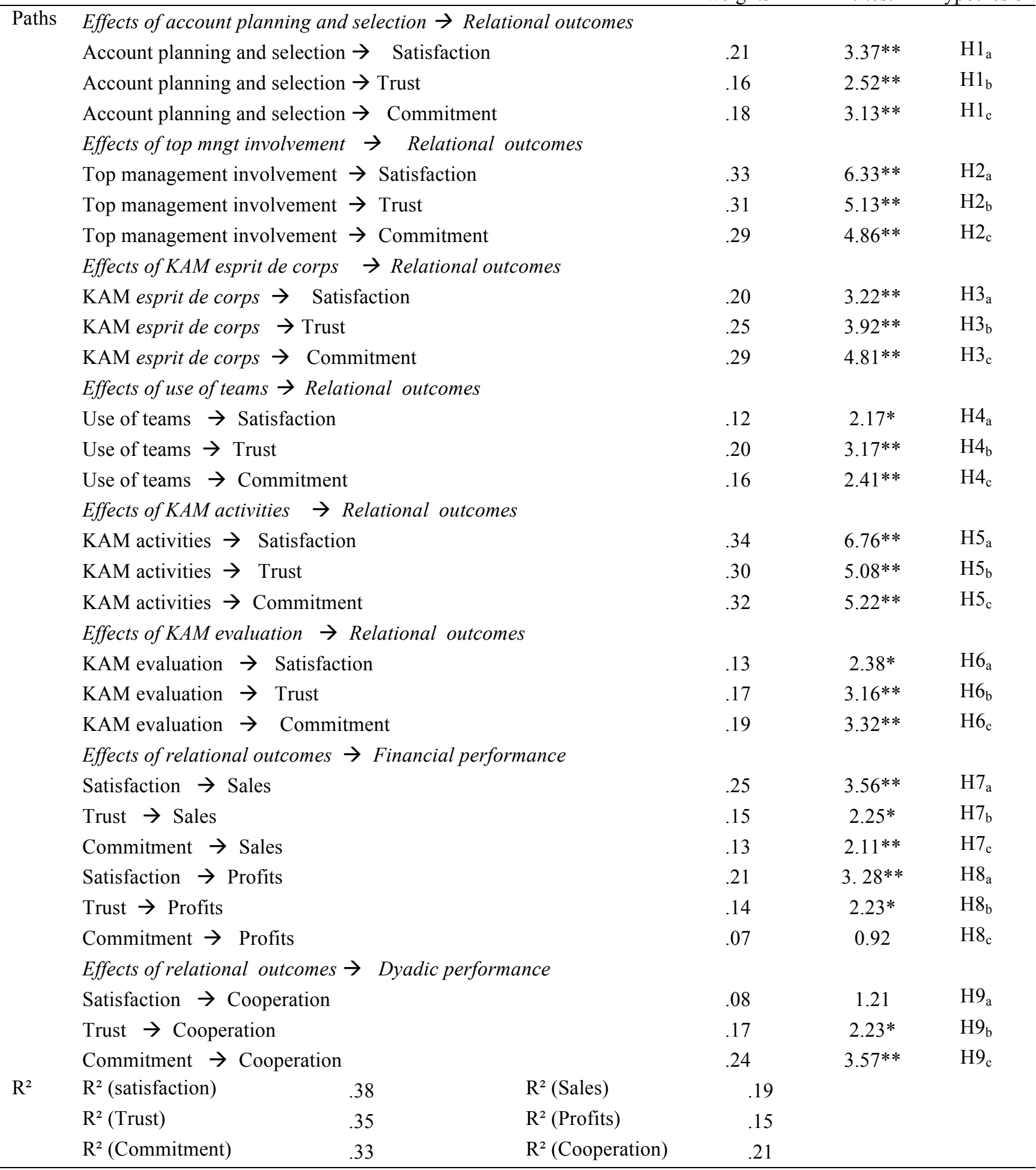

Notes: Reported values are standardized coefficients (betas); $\mathrm{R}^{2}$ : explained variance in endogenous construct; ${ }^{*} p<0.05$. $* * p<0.01$ 
Figure 1: Conceptual model

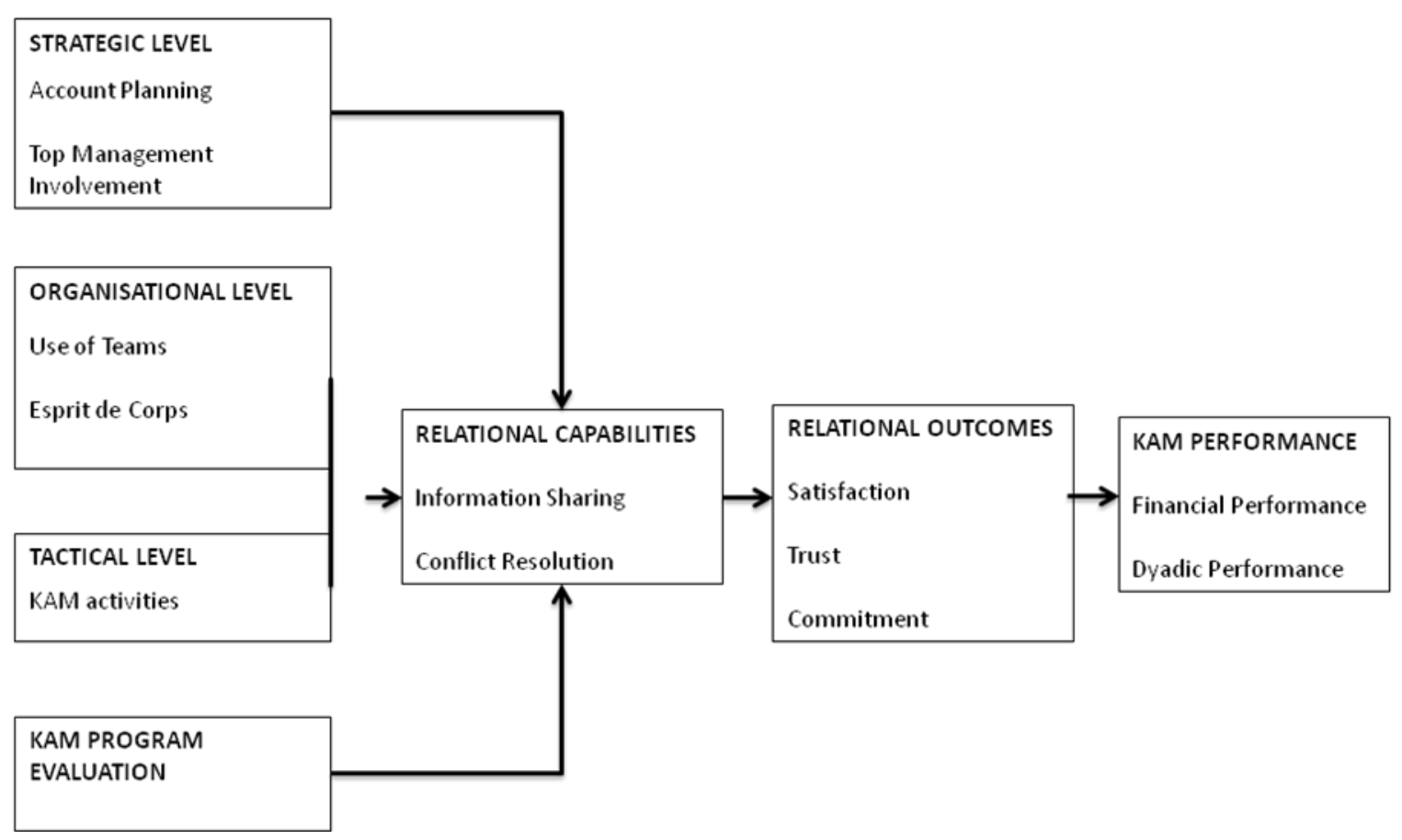

